\title{
1. The Janus face of EU law: A sociological perspective on European law making and its influence on social policy in the EU ${ }^{1}$
}

\section{Jean-Claude Barbier and Fabrice Colomb}

\subsection{INTRODUCTION}

In order to assess the influence exerted on 'social policy'2 by the European Union as one actor in a 'multi-level' governance system, it is essential to focus on law. What was emerging 20 years ago (Leibfried and Pierson 1995) is all the more visible now. The consequences of the gradual Europeanisation ${ }^{3}$ of law in the areas of social protection and social rights have been documented by political scientists (Falkner et al. 2005; Ferrera 2005; Falkner and Treib 2008; Martinsen 2009; Scharpf 2010; Höpner 2011) and by legal research (Davies et al. 2005; Rodière 2008; Bercusson 2009). However, sociological approaches analysing the

1 A different and shorter version of this chapter was published in J.-C. Barbier and F. Colomb (2012), 'EU law as Janus bifrons, a sociological approach to "Social Europe", in Jean-Claude Barbier (ed.), EU Law, Governance and Social Policy, European Integration online Papers (EIoP), Special Mini-Issue 1, Vol. 16, Article 2. Available at http://eiop.or.at/eiop/texte/2012-002a.htm. Accessed 22 May 2014.

2 'Social policy' is a shortcut, as is 'welfare policy' or 'the welfare state'. Empirically the scope of our research encompasses the entire systems of social protection, the systems of labour law and the provision of social (often public) services.

3 The Europeanisation of law is the gradual transformation of national law through the incremental insertion into it of elements of EU law that merge with it. In a sociological view, Europeanisation includes the socialisation processes of actors engaged in law making. 
phenomenon have remained rare (Vauchez 2008; Favell and Guiraudon 2011). This chapter is an attempt to bridge this gap. It focuses on the role of actors, both at the national and the EU level, as they are affected by the implementation of EU law, but also as they participate in EU law making in various ways. The central finding of our study lies in the ambivalent role of EU law and the variable support it commands among actors across the European Union. New social rights have been added over the years for individuals and new freedoms for firms. Yet, at the same time, threats to social protection and collective entitlements have appeared, because of the intrinsic asymmetry of EU law, and because of various spill-over effects. Actors are thus confronted with EU law as Janus-faced. One face promises opportunities, the other poses threats. Hence, there are two groups of actors, individuals or interest groups and organisations: those which are and feel threatened and those relishing and using the possibilities opened up for them by EU law. This opens up to a political bifurcation. What we found in meeting actors and in discussing with legal scholars is increased politicisation of EU law in the social domain: for this policy area, this is a new phenomenon.

The chapter proceeds in four steps. First, we describe our sociological approach and methods. We identify what we call the relevant 'social actors' (actors of social policy) in defined spaces, where EU law and governance are discussed. Following Bruno Jobert (1998, 2003), we call these spaces fora. In some cases, we are also able to situate them in 'arenas' where decisions are made. As no research is able to cover the whole area of social policy coordination at the EU level, we chose to focus on case studies that we considered highly significant. Secondly, we analyse the special institutional characteristics of EU law and contrast them with traditional social policy in the national context. Next, we deal with our central object, the ambivalence of EU law and explore it through themes that arose from the interviews and were 'triangulated' with views of legal scholars interviewed (and our review of the legal literature). Four aspects emerged as central: the subordinated status of social law at the EU level; the uncertain 'implementation' of EU law; the tension between economic and social rights, and, last but not least, the ambiguities of EU social citizenship. Finally, in an exploratory manner, we conclude by identifying coalitions of actors. This latter reflection leads to a broader theme - the comparative legitimacy of EU and national governments/ governance - which emerged as central in the evolution of the EU in 2014 after the completion of our sociological fieldwork. 


\subsection{A SOCIOLOGICAL VIEW OF RELEVANT ACTORS, OBSERVED IN THEIR FORA AND ARENAS}

'Social actors', that is, actors involved in the implementation of social policy in the broad sense chosen here (see note 1), play two main roles with respect to EU law. They are first involved as the object/target of EU law application, which, after being transposed, is incorporated into national law. For actors in the social domain, EU law is a relatively new concern. They are foremost national actors accustomed to national law and it is only because the reach of EU law has gradually extended into more and more areas of social policy (Rodière 2008; Hartlapp 2012; Barbier, chapter 11 in this volume) that they have become aware of its importance. We observe increasingly a second relationship to EU law resulting as a consequence of greater involvement with EU law. Secondly, social actors have developed judgements and opinions about EU law and criticise or, alternatively, praise EU law; they actively comply with it and promote it, or, alternatively, resist its implementation (for instance by resorting to non-application or to litigation) and try to influence its making. This role is not only observable, however, in national 'spaces'. It mainly takes place at the EU level, and the most common form it takes is lobbying in the EU fora. Hence, as table 1A.1 (in the Appendix) shows, one should not assume a clear-cut separation between 'national' and 'EU level' actors. Apart from national administrations and the formal EU institutions, sociologically, all the actors concerned with the application of EU law are in practice at the same time national actors and potential participants in fora at the EU level (this is why table 1A.1 has a similar list of categories at both levels). All actors also have a link to a personal/national history in one or more countries, even when they have acquired the role of participants in the 'Brussels fora'. Legal experts and the legal community in general also act both at the EU and the national level.

Before describing in some detail how we draw the map of the actors we consider 'relevant' for the purpose of the present research, it is important to be specific about what we call 'fora' and 'arenas' - the places where we meet them. We rely on Bruno Jobert's essential distinctions (Jobert 1998: 133-37; 2003), for whom fora and arenas are sites that have a predominant cognitive and normative dimension and where the formation of policies takes place. What informs the policy is what he calls the 'référentiel' (Jobert 2003), which can be translated as 
'frame of reference', where ideas and interests are not strictly separable. ${ }^{4}$ Actors participate in the formation of policies in three main types of fora: the 'fora of political communication', the 'fora of policy communities' and the 'scientific fora'. Jobert distinguishes fora, where debate about policies is conducted, from arenas, where a smaller number of actors participate, reach compromises and make decisions. How does this help the present research? We concentrate our observations on the 'fora of policy communities', where actors belonging to a particular area, or network of policy, meet. National 'policy communities fora' in the area of social services, for instance, are not insulated from EU-level social services fora. In these fora we identify the relevant actors for our interviews. Understanding the role of the 'scientific fora' in social policy is not a task with which we will deal in the present chapter. However, as researchers who have been involved in evaluation studies, in consultancy and in various scientific and dissemination activities over the last 20 years (Barbier 2008), we are aware that participation in these scientific fora provides highly informative long-term participatory observation from within. This position has many advantages for the identification of actors because policy communities fora and scientific fora overlap to some degree.

Our typology of actors (presented in table 1A.1) distinguishes five types. Types 1 and 2 group the social actors who manage social protection (unions have a special role and cannot be confused with nongovernmental organisations (NGOs)), which are providers of services (among them, commercial actors). Essentially we meet their representatives in professional organisations, but also some direct providers. Types 3 and 4 group together the formal institutions of the EU. Note that the Commission belongs to both types: in type 3, the Commission is considered both for its administrative and legislative roles (it shares the latter with the Council and the European Parliament). In type 4, alongside the Court of Justice of the European Union (CJEU, formerly ECJ), it is considered as the author of legal decisions. Four long (and essential) interviews were conducted with this type of actor, three with former référendaires in the Court and one with a legal specialist in the Commission administration. Finally, type 5, translators, although marginal for the present chapter, is nevertheless relevant for the whole interpretation because language is important for the very existence of law.

4 For readers more accustomed to English-language literature, the closest approximation, from which however Jobert wants to distance himself, would be the notion of 'paradigm', in Peter Hall's terms. 
What themes within social policy did we select? The themes were social services of general interest, labour law and social policy coordination. The interviews listed in table 1A.1 include two case studies conducted in France, but do not include three other case studies conducted by colleagues in the Netherlands (see Sol and Vos, chapter 12 in this volume), in the Czech Republic (Sirovátka, chapter 14 in this volume) and in the United Kingdom (see Koukiadaki, chapter 13 in this volume). The findings which are presented in the following sections are illustrated by quotations drawn from the interviews. The general interpretation of the corpus of interviews is the result of their comparison and 'triangulation' with views derived from discussions with legal scholars. Moreover, in the course of four years of research it was possible to meet some of our interviewees several times, and we were thus able to cross-check their answers with previous statements. As one of our interviewees in the DG Employment of the Commission noted in December 2010, fora are small worlds: 'it's a family, it's a club, and they are always the same, rotating among themselves'.

\subsection{THE FOREIGNNESS OF EU LAW: SPECIAL CHARACTERISTICS}

Law is part of the everyday life of citizens and meeting actors dealing professionally with EU law always brings to the fore a strong contrast with their idea of what law ordinarily is, namely 'national law'. The situation is different with EU law, because, we learn when talking to EU law makers, it has to be foreign in principle. Only a handful of our interviewees are conscious of this fact. European lawyer-linguists certainly know that it is part of their task. "We try and avoid sticking too closely to national terms', report two lawyer-linguists interviewed in the Council's administration. ${ }^{5}$ They are officially instructed to choose legal concepts that are different from any counterpart notion in national legal systems. Indeed, guidelines prescribe lawyer-linguists and reviser lawyerlinguists to avoid terms too closely linked to the national legal orders (Piris 2006). ${ }^{6}$ It is more surprising that even experienced legal scholars

\footnotetext{
5 Interview, March 2011, EU Council.

6 'En ce qui concerne la terminologie proprement juridique, il faut éviter les termes trop étroitement liés aux ordres juridiques nationaux', Guideline 5.3.2, p. 19, of the Guide pratique commun du Parlement européen, du Conseil et de la Commission à l'intention des personnes qui contribuent à la rédaction des textes législatifs au sein des institutions communautaires (French version 2003).
} 
are unaware of this fact. ${ }^{7}$ Indeed, compared with national law, the possibility of a 'common legal culture' is much more improbable with regard to EU law, which in principle is not grounded in any of the legal systems of the member states (Kjaer and Adamo 2011). The very fact that EU law is formulated and translated into many languages - 95 per cent of texts are now originally drafted in English ${ }^{8}$ - implies that it is written in a language cut from the ordinary legal consciousness, not only of the concerned actors, but also of citizens in general. A case in point here is the term 'workers', which is used in chapter 1 of Title IV of the Treaty (TFEU) (freedom of movement of workers), which means something different from the British legal term 'worker'. ${ }^{9}$ From interviews with members of the Court, ${ }^{10}$ we get the clear impression that this legal and linguistic strategy is part of the collective goal to build a sui generis legal order. No wonder then that, as we will see in the following section, a general puzzlement at the term 'social services of general economic interest' is constantly documented, and even more in the 'new' member states: in the Czech Republic, 'the concept is still studied'11 (see also Sirovátka, chapter 14 in this volume). In a way, some form of common 'misfit' with the classic term (i.e. public services) is incorporated ex ante into the legal system.

Apart from these basic linguistic problems (Kjaer and Adamo 2011), certain characteristics of EU law immediately stand in contradiction with the principles generally taken for granted in national law. They can be summed up easily in the following way. First, from the initial negotiations with member states about introducing new EU legislation to the eventual adoption of Directives and Regulations by the Council, the creation of EU law takes significantly longer than national legislation (Falkner et al. 2005; Falkner and Treib 2008). In EU fora and arenas, the process generally starts with the Commission drafting EU legislation

7 At a Copenhagen conference on social services (May 2011), a specialist of competition law confessed to the audience that he 'still had problems' with the term 'undertakings' used in EU law instead of the more common term 'firms' or 'companies'.

8 Interview, EU Council, March 2011.

9 Accordingly the French version 'les travailleurs' is distinct from the mainstream French 'salariés'; the German version, for its part, has 'die Arbeitskräfte' instead of the German classic 'Arbeitnehmer'.

10 For reasons of confidentiality we cannot be more specific about the identification of the four persons interviewed in 2010 and 2011.

11 Legal scholar, May 2011, Copenhagen conference on social services. 
(Directives and Regulations) after lengthy rounds of consultations. Certainly not all the Directives take as long to adopt as the Working Time Directive - three years between the Commission's proposal and the final passing in 1993.

Secondly, at the national level, the discussion of law happens in public spaces (nationale Öffentlichkeiten) through the media, in parliaments, and so on, and the debate extensively relies on political communication. A special form of political communication - spin - is organised by politicians and consultants for the purpose of marketing their ideas and persons to potential voters. Here we meet the third type of Jobert's fora, 'political communication fora'. None of this has strict equivalents or counterparts at the EU level. EU law has quite different characteristics: despite the increasing role of the European Parliament, it is predominantly a 'judge-made' or 'praetorian' type of law (Scharpf 1999). Despite the flowering forms of Europeanisation in every domain (Favell and Guiraudon 2011), there exist no equivalents for national public spaces for debating and for a distinct, identifiable legitimising process within a polity and a political community via its own political language. The lack of a clear process takes many forms that the actors, both at the national and at the EU level, keep experiencing in their mundane dealings with EU law. 'How to assess the legitimacy of the various NGOs that are supposed to represent us in Brussels?' asks a French Director of a social association; 'these people focus on commas and dots, they are trapped in their own "circus" in Brussels.' 12

In the last section of this chapter, we will come back to the difficult question of comparing EU and national law with respect to the empirical consequences of their basic characteristics upon the existence of a 'democratic deficit' at the EU level. As many have convincingly argued (Schmidt 2006), democracies experience similar limits at all 'levels'. In political science, it is common to distinguish between 'input legitimacy' and 'output legitimacy' (Scharpf 1999). However, in sociological terms, the objectification of legitimacy is definitely more empirically complex. In the next section we turn to the actors' experience when it is focused on social policy.

12 Interview, March 2011. 


\subsection{THE OVERARCHING ASYMMETRY BETWEEN ECONOMICS AND 'THE SOCIAL'}

Our research took place just after the French and Dutch referenda and the debate over the 2006 Service Directive in which actors and citizens for the first time voiced their discomfort with EU law and its impact on their social rights and social policies. This was an 'intermediary' period between the 'benign neglect' shown in the past by voters and the increased 'Euroscepticism' emerging from the crisis after 2008. The combined effect of negative integration on the one hand, and spill-over effects on the other, took time to really bite in the social domain (Ferrera 2005; Martinsen 2009; Barbier 2013), where positive integration has always been hardest to achieve. In the following we review the four dimensions which emerged as significant for social actors and at the same time were considered relevant by the legal scholars interviewed: the subordination of national law, the uncertain process of implementation, the opposition between economics and solidarity, and the limited hopes opened up by the Charter of Fundamental Rights and social citizenship at the EU level.

\subsubsection{Subordination and the Practical Consequences of EU Law Supremacy}

NGOs and unions, as well as non-profit organisations engaged in welfare provision, view social protection institutions as essential and key elements of the ordinary functioning of European societies, both politically and economically; social law is core for them because it is able to identify deserving individuals in order to organise redistribution on a legitimate basis. These organisations are disturbed by the immense contrast at the EU level where these realities are only seen as legal exceptions and funding for reasons of solidarity enjoys only marginal attention. 'The EU tends to see citizens as consumers on a market for indistinct services, but the associations have always made economic things their own way, which is different and not recognised legally', says a specialist of social services in a French NGO. ${ }^{13}$ Furthermore, the contrast emerges not only between EU law and national legal orders, but also between the EU legal order and international labour and other social standards (Bercusson 2009; Supiot 2009; Akandji-Kombé and Leclerc 2001; Roman 2010). Contradictions remain among different legal orders

13 Interview, May 2010. 
and 'it is odd that the European Social Charter - Council of Europe does not feature among the sources of EU law', a German law professor tells us. ${ }^{14}$ The legal community is divided, a French law professor observes, especially with regard to the increasing role of economics in law: 'Economics is a fragile discipline, which is rejected by many legal scholars. Its intellectual value remains poor and ends up as contradicting the proportionality principle.' ${ }^{15}$ For a specialist of human rights, and their internationalisation, the famous lawyer Mireille Delmas-Marty, the EU legal order lacked consistency because of fragmentation among the pillars introduced by the Maastricht Treaty (Delmas-Marty 2006, p. 264). She expressed her regret that respect for human rights cannot be invoked legally as part of a European public order against market rules and is not applicable to firms (Delmas-Marty 2004, pp. 151-2). For their part, national legal systems derive their consistency from the fact that under an autonomous constitutional order, they are covering all areas of law. Consequently, because of their long history and embeddedness in the social reality of member states' legislation, social rights and collective entitlements are fully recognised by the courts of the country and are a constitutive part of the legal system. These rights have legally binding effects and are fully 'justiciable' at the national level. This is not the case for social rights at the EU level; for instance for the right to collective action (Bercusson 2009). 'The right to strike is fundamentally jeopardised at the national level by the potential legal contestation of employers that draw arguments from EU law on freedoms of movement. This is especially visible in the United Kingdom.' ${ }^{16}$ Similarly, the fear of collective authorities to be seen as trespassing EU law leads them to increase their recourse to cumbersome tenders putting associations in competition with all sorts of private actors, thus disadvantaging small associations. ${ }^{17}$

At the EU level, the role of social law (labour and social protection law) has remained marginal because it always was to remain, at least officially, the preserve of member states' jurisdiction. Despite the evolution of a social dimension, for example in the important domain of anti-discrimination legislation (de Schutter 2004), the initial, economic logic has prevailed in the European integration process and economic and social rights are still not treated similarly in EU law, even after the formal adoption of texts establishing social rights. Social rights are only relevant

\footnotetext{
14 Interview, April 2011.

15 Interview, February 2010.

16 Interview, unionist, Brussels, March 2011.

17 Interview, Brussels NGO, February 2012.
} 
in relation to the functioning of the market (or, conversely, in case they affect negatively the market's functioning). Especially in the older member states, EU social law is often considered as marginal in comparison to national law. This is for instance the case, observes a unionist, for legislation on working time: 'the basics of legislation are national, and what we have in France is difficult application, but only in certain sectors'. ${ }^{18} \mathrm{EU}$ 'social legislation' often appears as if concentrated on general principles of little actual consequence, because of lack of 'justiciability' (Roman 2010). This is the case for the long list of rights that feature in the chapter 'Solidarity' of the European Charter of Fundamental Rights. 'There is a lack of innovation in the legal services of the Commission, but one needs to find new legal principles for protecting national social arrangements', a legal specialist in the Commission notes. ${ }^{19}$ Seen through the EU legal angle, these rights remain de-contextualised, de-territorialised and, thus far at least, have never constituted a serious legal basis for upholding justiciable collective rights for a majority of European citizens, who are covered by their own national legislation.

\subsubsection{The Vagaries of Implementation: What about Actual Rights?}

Social actors are also dismayed at the extremely long and unpredictable process of implementation of EU law: only the strongest actors are able to summon sufficient financial resources and are well incorporated in EU fora and, even more, in arenas, where they are able to use this feature of EU law to their advantage. The main instrument is lobbying but litigation is another well-known strategy. The interminable revision of the Working Time Directive is a case in point here, which took five years and failed to pass (see Rogowski, chapter 6 in this volume). Unions are not able to wait for such long spans of time and they can only rely on their national regulations, but they fear difficult problems in the future, especially with regard to social protection schemes. ${ }^{20}$ In social protection and in public as well as non-profit services, actors who contest the extension of EU competition law (because services are deemed to be of an 'economic' nature; see Koukiadaki, chapter 13 in this volume), have been waiting for the European Commission to introduce specific rules, but until December

\footnotetext{
18 Interview, French unionist, June 2011.

19 Interview, February 2011.

20 Interview, unionist, March 2011.
} 
2011 with no result. ${ }^{21}$ As a result, from the asymmetric point of view of EU law, social care or childcare services are still seen as comparable in principle with large service networks (the railways, electricity). It is one of the topics on which the legal community appears divided (Krajewski et al. 2009), but where private firms implement apparently successful strategies in order to delay the adoption of new provisions and increase their market share. Particularly in the Netherlands, the case of social housing is a controversial but typical case in point (Sol and Vos, chapter 12 in this volume).

More generally, as far as implementation of law is concerned, the process at the EU level is decidedly more arcane, obscure, uncertain and risky than the already obscure, specialised and uncertain process at the national level. This situation is, inter alia, the outcome of the length of the chain of actions that take place from the initial drafting to the eventual application (Falkner et al. 2005; Hartlapp 2007). A situation can easily prevail whereby, unless explicit litigation is started, EU law may remain a 'dead letter', as Falkner and Treib (2008) have observed for Central and Eastern European countries (see Sirovátka, chapter 14 in this volume). Actors in the social protection and non-profit organisations whose representatives we met in France and Germany reported that they had little, if any, 'grip' on the law-making process, all the more so as there is no homogenous 'public space' available in which to develop their usual strategies. 'The national adaptations of EU law are much more opaque than the counterpart processes for national law: associations were kept in the dark for instance, by the French government with respect to the transposition of the 2006 Service Directive.' 22 The fragmentation of the numerous fora and arenas where decisions are prepared and eventually taken may even lead to division within and among NGOs according to their fields of intervention, ${ }^{23}$ which sometimes results in the fragmentation of issues debated in the European Parliament. ${ }^{24}$ At times, this goes

21 Several interviews with representatives of French and German non-profit organisations, October 2010. A large literature is devoted to the matter. See for instance Krajewski et al. (2009). See also Barbier (chapter 15 in this volume) for the failed attempts of cooperation between social actors in France and Germany in the late 1990s. On 20 December 2011, a new set of legislation was brought forward by the Commission (see also discussion later in this chapter).

22 Interview, French NGO, social services expert, May 2011.

23 Multiple interviews, French associations, September 2009, October 2010, March 2011.

24 A case in point in this respect has been the creation of a special European Parliament group dealing with situations of extreme poverty (promoted by the 
so far as to make EU law preparation and adoption appear as 'un procès sans sujet' (a process without a subject): this is what a specialist in a French ministry, directly involved in the judicial discussions of case-law, tells us: 'EU law is in the life of every one of us, but no one really draws the consequences; this is the "steamroller" of EU law. ${ }^{25}$ It is striking to listen to high-level officials in the national administrations, ${ }^{26}$ especially and directly concerned with the application of EU law, reporting that the whole process is beyond the control of its direct actors. A somewhat deterministic reading of recent jurisprudence in social matters (Supiot 2009; Scharpf 2010) also lends support to a view of EU law as a complex social process without identifiable authors. This impression is corroborated by the discovery that even with careful analysis of the production of legal texts it is difficult, if not impossible, to identify anything equivalent to the 'legislator's intention' that exists at the national level (Kjaer and Adamo 2011, p. 104, p. 109) and this situation is reinforced by the 'foreignness' of EU law for ordinary citizens.

\subsubsection{Economics vs. Solidarity: Individual vs. Collective, Mobile vs. Immobile}

When we meet social actors, they most often link this foreignness to a perception of EU law as being 'economic'. NGOs, for instance, are deemed to be 'undertakings' and to deliver 'social services of general economic interest', whereas in most countries they have historically been considered as contributing to public services (see Koukiadaki, chapter 13 in this volume). 'It is really a paradox that we, associations, are now part of economic law', says a specialist of social services in a French NGO. ${ }^{27}$ This perception certainly does not contradict a significant part of the legal literature. In the economic point of view actively promoted by the CJEU (Neergaard 2009), market provision of social services is always a priori seen as the best outcome. In the words of one of the Commission's legal specialists, the best and most efficient way of providing social services consists in the universal recourse to 'vouchers' that allow

NGO ATD Quart Monde), as opposed to mainstream poverty action (interview, French association, March 2011; confirmed by another interview with the EU-level correspondent of the same NGO, April 2011).

25 Interview, legal expert, French ministry, February 2011.

26 Several interviews (September-December 2010) in the social ministries and in the Foreign Ministry in Paris.

27 Interview, May 2010. 
consumers to buy their services from whatever providers they choose. ${ }^{28}$ 'Economisation' of law is stressed by many lawyers. When it comes to 'public goods', for instance, among which social protection traditionally features, the CJEU uses a predominantly economic mode of reasoning (Prosser 2005; Supiot 2005, 2009; Deakin and Sarkar 2008; Neergaard 2009, pp.44-7). As a consequence, individual rights are privileged for individuals, but also for firms, and collective entitlements are disregarded (Camaji 2008) when not directly combated, or considered as an exception to the rule, only legitimate in certain cases. The CJEU is active in promoting mainstream economic ideology which combines the promotion of the market for reasons of efficiency and transparency with the promotion of 'fundamental rights'. It is certainly not by chance that in its case-law this court has taken to declaring the free movement provisions 'fundamental freedoms', an expression that does not feature in the Treaty. In strategic terms the court thus strives to put 'fundamental rights' (as inherited from national legal systems and the international norms of the International Labour Organisation and the European Convention on Human Rights) (Roman 2010) and allegedly 'fundamental' economic freedoms on the same symbolic footing. This equivalence is directly challenged by a significant part of the legal literature, and the actors we meet are well aware of this contentious aspect of EU law. The majority of non-profit providers of social services or social benefits have had great difficulty, especially in certain countries (notably France, Belgium and Germany) ${ }^{29}$ in finally accepting that the services they provide are 'economic'. Some still resist the qualification, as for instance the European Trade Union Congress (ETUC). ${ }^{30}$

What strikes social actors even more, in contrast to national law, is that, in spite of the rhetorical presence of 'solidarity' as a legal notion, there is little, if any, effective substantive solidarity at the EU level. To put it more strongly, solidarity is the essential legal category that allows for exceptions to economic law. The famous 1993 Poucet-Pistre rulings ${ }^{31}$ constitute a key reference in this respect, because this case-law has

\footnotetext{
28 Professor J.B. Cruz, conference on social services, Copenhagen, May 2011.

29 Interview, French association, February 2010; German association, May 2011. See also Barbier (2013).

30 Interview, February 2010, ETUC. In 2008, the ETUC made a proposal for a 'Social Progress Clause' Protocol aiming at counterbalancing the asymmetry between 'social' and 'economic' rights.

31 Joined Cases C-159/91 and C-160/91 Poucet and Pistre [1993] ECR I-637 $246,250$.
} 
historically established (actually, created) the criteria of what can be seen as a typical social programme that is exempted from complying with competition rules. Ironically, far from being protected by the market, social protection is thus 'sheltered from the market' (see Koukiadaki, chapter 13 in this volume). This encapsulates the crucial de facto opposition in EU law between individual rights and collective entitlements. It should be stressed that the two crucial pillars of social security constituting essential tenets of the classic welfare state, namely state pensions and state healthcare, are not based on any provision of primary law, but on the fragile ground of a 1993 ruling that could be reversed (Driguez 2010). As a result of the gradual extension of the reach of EU law, non-profit providers of social services and their organisations report the dangers they see for the continuity and quality of the services they most often deliver to vulnerable people: 'With the inadequate levels of obligations for tenders, there is a growing fear of losing the contracts, thus a danger for the continuity and quality of services. ${ }^{32}$ They tell us that they feel powerless in this domain, because the only action possible is through lobbying and mobilising in fora where 'rules for representation are obscure'. ${ }^{33}$ At worst, debate occurs only as a result of litigation, as in the Laval and Viking cases or in the 2010 'Commission versus Germany' case where national arrangements negotiated between social partners were threatened by the application of EU legislation on economic freedoms. ${ }^{34}$ 'Negative' notoriety of EU law has thus recently provided the main opportunity for debating social policy across the Union. In contrast to the promotion of economic thought, the attention paid by $\mathrm{EU}$ institutions $^{35}$ to 'solidarity' is limited (Ferrera 2005; Barbier 2008). This process was exceptionally illustrated in 2014 during the preparation of the elections for the European Parliament.

\subsubsection{The Ambiguities of European Citizenship and the Limits of the Charter}

Despite general reluctance among social actors in seeing advantages of European citizenship when it comes to collective entitlements and social services, numerous NGOs among our interviewees are fighting for the

\footnotetext{
32 Interview, French NGO, September 2010.

33 Interview, French NGO, March 2011.

34 Interview, European Trade Union Institute (ETUI), March 2011.

35 Interview, DG Employment, December 2010.
} 
promotion of individual rights and are keen on using litigation strategies. ${ }^{36}$ National organisations are often taken aback, however, when, for instance, in the struggle against poverty and the support for social protection schemes, they experience contradictions between these two goals that are pursued together in a national context without difficulties. ${ }^{37}$ They are also happy to obtain protection of their national systems purely on a national basis, with little consideration for the systems in other member states. ${ }^{38}$ In actual fact, since its inclusion in the Maastricht Treaty, European citizenship has unfortunately remained, de facto, the preserve of only a limited number of citizens in Europe; for example, those who are able and willing to move. This is illustrated in the formulation of the Treaty: the only classic social rights presented in it are those of migrants (article 21.3 TFEU). In fact, one dimension that is perhaps difficult to understand for non-specialists, and the citizens themselves, is that EU law in the area of citizenship targets situations of movement between member states (Rodière 2008, p. 195, p. 265). One aspect of anti-discrimination is linked directly to movement - that is, the prohibition of discrimination on 'grounds of nationality'. However, other aspects are much more encompassing, because they concern all the most common grounds for discrimination ('sex, gender, racial or ethnic origin, religion or belief, disability, age or sexual orientation') (article 19 TFEU). Here again, the ambiguous 'Janus-faced' nature of EU citizenship appears: on the one hand, it pertains to fundamental rights. But on the other hand, all the major components of EU citizenship de facto concern citizens who are keen on moving and do actually move, except the right to vote for the European Parliament. ${ }^{39}$ The main exception in terms of significant European influence on social and labour rights has been equality between men and women, because of the unexpected spill-over effects of the initial provisions in the Treaty of Rome (namely, ex-article 119; Davies et al. 2005). The great majority of the 26 legal experts we have interviewed since the 2009 implementation of the Lisbon Treaty share the view that the reference to the Charter of Fundamental Rights (its article 6 TEU) will not substantially modify this situation in

36 As one French NGO member reports (January 2010), it has been easier so far to introduce litigation on the basis of the Convention on Human Rights, but his association expects new openings from the future extension of implementation of the Charter of Fundamental Rights (article 6 TEU).

37 French NGO, interview, February 2009.

38 German NGO, interview, May 2011.

39 The number of people working in a country different from their own is estimated at between 1 and 2 per cent of the working age population. 
the future. 'Despite face-saving exercises concerning some member states, the legal status of social rights is not modified by its reference in the new Treaty.' 40 The protection of the right to strike, however, is explicit in article 28 of the Charter, and unionists aim at influencing the application of law on this subject through systematic monitoring and intervention in legal cases before national jurisdictions. ${ }^{41}$ As was already the case before the adoption and the reference to the Charter, in matters of human rights, the Court of Justice's case-law referred to legal sources originating in member states' legislation and constitutions, as well as to the European Convention on Human Rights.

Finally, the overall impression documented among our actors in the first and second groups of table 1A.1 is legal uncertainty as to the future sustainability of healthcare and pension systems, of labour law and collective agreements, and of social services of general interest, that is, public services. This impression is shared by a majority of the legal experts among the interviewees, but for lawyers, 'legal security' is a concept pertaining to their trade; what French law for instance calls sécurité juridique. ${ }^{42}$ When sociologists, on the other hand, deal with legal uncertainty or insecurity, they are using a different notion that encapsulates the perceptions of actors.

\subsection{CONCLUSION: THE BIFURCATED LEGITIMACY OF THE EU LEGAL ORDER}

What conclusions can we draw from this exploration of the views and actions of social actors with regard to their relationship to EU law? The comparison of their points of view with in-depth discussion with legal experts (as well as the taking stock of focused case-law in social services and labour law) shows that the fears of social actors cannot be dismissed as imaginary. The sociological approach is able to document this. As the French president of an influential non-profit organisation told a conference organised by the social services of general interest (SSGI) lobby group in Paris, 'there exists real or alleged legal uncertainty'. ${ }^{43}$ The range

\footnotetext{
40 Interview, official, Council, March 2010.

41 Interview, ETUC, February 2010.

42 The French Conseil d'État speaks of 'qualité et prévisibilité de la loi' in its Rapport public (2006); Craig and de Búrca, about 'legal certainty' (Craig and de Búrca 2008, p. 555).

43 Collectif SSGI, A New Deal, the Almunia-Barnier 'package', Paris, 2 February 2012.
} 
of actors that we have interviewed for the present exploratory study is obviously not representative of the full variety of social actors in the EU and national fora and arenas we have been targeting. The main bias of our survey is with regard to the Central and Eastern member states, despite the findings drawn from the Czech case studies (see Sirovátka, chapters 7 and 14 in this volume). A different bias has also been inherent to the angle chosen by the authors of the present chapter, since there is only a limited number of interviews with commercial actors which essentially are only used as a 'mirror' for the perceptions of traditional social actors, the non-profit and public ones. This second bias, however, is somewhat mitigated by the consideration of the UK, Dutch and Czech case studies, where private for-profit provision of services is considerably higher. All in all, the significant material collected draws a picture of endemic contestation by social actors, fears for their future work as non-profit service providers and fears for the future of their national labour law. Because of its exploratory nature, the material is nevertheless insufficient for a comprehensive discussion of the overall legitimacy of EU policies in the areas of social legislation. Yet it is interesting to consider in that it points to two essential conclusions.

\subsubsection{Expected and Unexpected Alliances in the Fora and Arenas}

First, EU law is far from being only legitimised by the legal discourse articulated by a small group of judges and lawyers. Support originating from commercial actors is documented at the national and the EU level by the literature on European integration (Scharpf 1999; Schmidt 2006) and confirmed by our survey. "The growth of private provision in long-term care for the elderly is a result of legislation favouring more competition', a French for-profit firm tells us. ${ }^{44}$ Two German lobbyists and a German law professor concur in praising the situation in this sector in their country: the "flexibility of services for the elderly has been greatly increased since the reform of Pflegeversicherung which introduced competition', they observe. ${ }^{45}$ Less expected, a priori, we also document support by NGOs at the EU level. Strongly supporting individual rights, the legal community, for its part, seems to be united, while, on the other hand, a minority of it points to the destabilising of collective arrangements (Bercusson 2009; Guinard 2009; Supiot 2009), or to the inconsistency of the EU legal order. Some of our interviewees in

\footnotetext{
44 Interview, French long-term care provider, September 2009.

45 Interviews, January 2012, March 2011, September 2010.
} 
the 'legal services' of the Commission ${ }^{46}$ report their preference for devising correcting mechanisms, in line with the normative aim of trying to 'nest' the systems of social protection (Ferrera 2009), put forward by political scientists or by lawyers (Bercusson 2009). Unions and social security actors are dismayed. ${ }^{47}$ In times of crisis, they are joined by new political actors. ${ }^{48}$

But one of our main empirical findings is that NGOs and various advocacy coalitions enter in essential alliances with the legal community, because they share the substantive project of promoting the individual rights of a variety of groups, with the key support of the European Commission. The quest for this type of legitimacy was visible from the early stages in the life of the Court of Justice. This provided it with a key resource, 'moral high ground': the gradual extension of reference to 'human rights', or 'fundamental rights', on the other hand has disturbed the traditional references of traditional social actors, more accustomed to dealing with social rights, social protection and social services. An essential challenge for future sociological studies of the Europeanisation of law is to identify the changing social forces supporting/opposing the legitimacy of EU law in its ordinary functioning. A wealth of literature has insisted on the well-documented fact that economic interests and big firms are at the forefront of this support, and play a key role (Streeck 1998; Scharpf 1999). But what is less stressed in general is that, apart from the overall liberalising of the economy, consistent with the promotion of powerful cross-national economic interests, EU law has also decidedly promoted and safeguarded some rights of individuals from a liberal equality point of view, against classic raison d'État. A case in point is the prominent position of the 'anti-discrimination' principle in EU law, which features, along with the principle of equality between men and women, in the Treaty on the same level as European citizenship (article 2 TEU, articles 18 and following TFEU). Anti-discrimination is at

\footnotetext{
46 Interview, Commission, June 2010.
}

47 In order to counteract moves by member states, by employers or by the Commission, EU-level union representatives have started devising strategies of litigation in the hope of achieving a more balanced consideration of social rights as against economic freedoms (interview, ETUI, September 2010; see also Bercusson 2009).

48 An interesting case in point is Jérôme Vignon, the former Director of Social Cohesion in the DG Employment and Social Affairs, now retired. In the SSGI conference already mentioned above, addressing the Commission, he declared to the audience: 'Has the moment not arrived today, with the huge deficit of provision in social housing and childcare, for the EU to create new social safeties?' (2 February 2012). 
the same time an excellent illustration of the Janus-faced nature of EU law. It is certainly not by chance, then, that its passionate defence is part of all the texts written by former judges of the ex-ECJ. Nor is it surprising to see how the European Commission has eagerly attached its political communication to this aspect of EU politics. ${ }^{49}$ Nor is it by chance that the first Report on Fundamental Rights (2010) established by the Commission enumerated a list of individual situations that EU law was especially organised to protect: the rights of women to equality, the special situation of the Roma people, the rights of the disabled. Along the same lines, it is also quite logical that the Court and the Commission concur in defending the cause of marginal and excluded people: people asking for assistance, irrespective of their citizenship rights (Ferrera 2005), poor people, homeless people, and so on and so forth. The otherwise uncertain legitimacy of EU law, often criticised for its privileging powerful economic interests, has found a key basis for indispensable balance there. We just have to read Judge Mancini's plea to understand the logic of this support, when, with the hindsight of 30 years of case-law, he drew a list of individuals that had nominally benefited from the implementation of EU law - all chosen, note, in the realm of anti-discrimination:

They will do well to look closely at the Court's case law and remember how many of Europe's citizens have benefited directly of the Court's rulings. They will for example remember the Belgian air hostess who claimed the right to the same rate of pay as her male colleagues [Defrenne - case 43/775 (1976)], the British nurse who objected to being compelled to retire several years earlier than a male [Marshall - case 152/84 (1996)], the German woman who was prevented from getting a job as a canteen assistant at Cagliari university by a practice of discriminating against non-Italians [Scholz - case 419/92 (1994)], the French student who wanted to study cartoon-drawing at an academy of fine arts in Belgium and was required to pay a fee not imposed on Belgian students [Gravier - case 293/83 (1985)], the Greek hydrotherapist who asked only that his name should not be distorted beyond recognition, when transliterated by an over-zealous German registrar of marriages [Konstantinidis - case 168/91 (1993)] and above all the millions of consumers who are the direct beneficiaries of a common market founded on the principles of free trade and undistorted competition. What citizen of Europe has not been assisted in some way by the rulings of the European Court in Luxembourg?

(Mancini 2000, p. 193)

49 The promotion of the rights of the Roma people led to various conflicts between member states and the Commission. 
This points to the existence of a rarely stressed alliance in favour of active support for EU law's legitimacy. Large economic interests motivated by the extension of the frontiers of the market are in fact allied with groups of citizens who have a particular stake and pursue the particular advocacy of a cause. For instance, an objective and paradoxical alliance exists between the EU Commission, presently promoting the interests of homeless people, the NGO which leads this advocacy coalition in Brussels (FEANTSA) ${ }^{50}$ and the private for-profit providers of housing across the member states. This coalition stands directly against the interests of social housing corporations in the Netherlands - which, according to statistics and to the Commission's view - are 'abnormally' aimed at rich or middle class households (see Sol and Vos, chapter 12 in this volume). A similar political stance was presented in February 2012 by an official from DG Competition, when, in a conference, she told that when it came to 'upper class housing for the elderly',51 the social character was doubtful. Another case concerns the NGOs promoting a better recognition of extremely rare diseases which were very active in the coalition of actors that eventually achieved the adoption of the 2010 Directive on cross-border healthcare. ${ }^{52} \mathrm{~A}$ more systematic review of this phenomenon is called for.

\subsubsection{Contestation and Uncertainty}

Secondly, social actors - the unions, the non-profit providers of services, the key actors in the traditionally 'public' provision of social security benefits - have hardened their defiance and contestation of the EU master discourse. They are certainly not inactive and they are being increasingly heard, as the referendums have shown (Barbier 2008). More recently, a case in point has been the project of a renewed extension of the single market. The 2010 Monti Report to the president of the Commission is typical because it exemplifies a new consciousness among political arenas in Brussels: 'Member states, political groups and stakeholders', it writes, are 'conditional supporters' and it notes that 'a re-launch of the

50 European Federation of National Organisations Working with Homeless People. A comparable social policy NGO is EAPN, the European Anti-Poverty Network, representatives of which we interviewed in France and at the EU level in March 2011. Normative and political conflicts abound among the EU-level NGOs.

51 SSGI conference, 2 February 2012.

52 Interview, March, 2011, French ministry. 
single market is likely to meet serious opposition'. ${ }^{53}$ The problematic situation is exacerbated by doubtful if not negative economic outcomes, the understanding of which goes far beyond the theme of the present chapter. The economic crisis provides a context in which uncertainty keeps increasing and EU and national elites appear divided. The moving and dynamic context in which we find our interviewees does not resemble an inexorable development just led by de-contextualised law, as Fritz Scharpf seems to conceive of it (Scharpf 2010). New proposals for legislation regarding the services of general economic interest put forward in December 2011 by the EU Commission provide an illustration of the fact that, however incremental, margins of manoeuvre are still available to actors in the social domain. ${ }^{54}$ Nevertheless, with the hindsight of the previous 20 years (Barbier 2008, 2013) nothing is secured and initial 'social' hopes in the new Lisbon Treaty (Ferrera 2009) have failed so far to materialise decisively. In terms of the interaction between the various instruments of governance, law and macroeconomic coordination have undoubtedly dwarfed the role of the 'soft law' modes of governance. There is every reason to believe that this primacy will obtain for the medium-term future. As the fieldwork for this chapter had been completed in the years 2010-2012, many echoes of the concerns we identified were heard during the run-up to the European elections in May 2014.

\section{BIBLIOGRAPHY}

Akandji-Kombé, J.-F. and S. Leclerc (2001), La charte sociale européenne, Bruxelles: Bruylant.

Barbier, J.-C. (2008), La longue marche vers l'Europe sociale, Paris: PUF.

Barbier, J.-C. (2013), The Long Road to Social Europe, Abingdon: Routledge.

Bercusson, B. (2009), 'The impact of the case-law of the European Court of Justice upon the labour law of the Member States', Labour Law and Social Europe: Selected Writings of Brian Bercusson, Brussels: ETUI, pp. 459-90.

Camaji, L. (2008), La personne dans la protection sociale, recherche sur la nature des droits des bénéficiaires des prestations sociales, thesis, Paris: Dalloz.

Craig, P. and G. de Búrca (2008), EU Law, Text, Cases and Materials, Oxford: Oxford University Press.

53 'A New Strategy for the Single Market', that was to be followed by a Communication of the Commission in 2011 (COM 2011206 final 13.4.2011).

54 Adaptations of the legislation by the Commission in December 2011 can certainly be seen as pertaining to these existing margins of manoeuvre. 
Davies, P., A. Lyon-Caen, S. Sciarra and S. Simitis (2005), European Community Law: Principles and Perspectives, Liber Amicorum Lord Wedderburn, 2nd ed., Oxford: Clarendon Press.

De Schutter, O. (2004), 'The Implementation of the EU Charter of Fundamental Rights through the Open Method of Coordination', Jean Monnet Working Paper 07/04, New York School of Law.

Deakin, S. and P. Sarkar (2008), 'Assessing the long-run economic impact of labour law systems: a theoretical reappraisal and analysis of new time-series data', Industrial Relations Journal, 39 (6), 453-87.

Delmas-Marty, M. (2004), Les forces imaginantes du droit (I): Le relatif et l'universel, Paris: Seuil.

Delmas-Marty, M. (2006), Les forces imaginantes du droit (II), Le pluralisme ordonné, Paris: Seuil.

Dezalay, Y. (2007), 'De la défense de l'environnement au développement durable, l'émergence d'un champ d'expertise des politiques européennes', Actes de la recherche en science sociale, 166-7, 66-79.

Driguez, L. (2010), 'Les institutions de protection sociale face au droit de la concurrence: confirmations ou inflexions?', Revue de droit sanitaire et social, $\mathbf{6}$, 1048-59.

Falkner, G. and O. Treib (2008), 'Three worlds of compliance or four? The EU-15 compared to new member states', Journal of Common Market Studies, 46 (2), 293-313.

Falkner, G., O. Treib, M. Hartlapp and S. Leiber (2005), Complying with Europe: EU Harmonization and Soft Law in the Member States, Cambridge: Cambridge University Press.

Favell, A. and V. Guiraudon (eds) (2011), Sociology of the European Union, London: Palgrave Macmillan.

Ferrera, M. (2005), The Boundaries of Welfare: European Integration and the New Spatial Politics of Social Protection, Oxford: Oxford University Press.

Ferrera, M. (2009), 'The JCMS annual lecture: national welfare states and European integration: in search of a "virtuous nesting", Journal of Common Market Studies, 47 (2), 219-33.

Guinard, D. (2009), Réflexions sur la construction d'une notion juridique: l'exemple de la notion de Services d'intérêt général, PhD thesis, Université Paris-Sud XI, Faculté Jean Monnet.

Hartlapp, M. (2007), 'On enforcement, management and persuasion: Different logics of implementation policy in the EU and the ILO', Journal of Common Market Studies, 45 (3), 653-74.

Hartlapp, M. (2012), 'Deconstructing EU old age policy: Assessing the potential of soft OMCs and hard EU law', in Jean-Claude Barbier (ed.), EU Law, Governance and Social Policy, European Integration Online Papers (EIoP), Special Mini-Issue 1, Vol. 16, Article 3, http://eiop.or.at/eiop/texte/2012-003a.htm. Accessed 22 May 2014.

Höpner, M. (2011), 'Der Europäische Gerichtshof als Motor der Integration: Eine akteursbezogene Erklärung', Berliner Journal für Soziologie, 21, 203-29.

Jobert, B. (1998), 'La régulation politique: le point de vue d'un politiste', in J. Commaille and B. Jobert (eds), Les métamorphoses de la régulation politique, Paris: LGDJ, pp. 119-44.

Jobert, B. (2003), 'Europe and the recomposition of national fora: the French case', Journal of European Public Policy, 10 (3), 463-77. 
Kjaer, A.L. and S. Adamo (eds) (2011), Linguistic Diversity and European Democracy, Farnham: Ashgate.

Koukiadaki, Aristea (2012), 'EU governance and social services of general interest: when even the UK is concerned', in Jean-Claude Barbier (ed.), EU Law, Governance and Social Policy, European Integration online Papers (EIoP), Special Mini-Issue 1, Vol. 16, Article 5 http://eiop.or.at/eiop/texte/2012-005a.htm. Accessed 22 May 2014.

Krajewski, M., U. Neergaard and J. van de Gronden (eds) (2009), The Changing Legal Framework for Services of General Interest in Europe: Between Competition and Solidarity, The Hague: TMC Asser Press.

Leibfried, S. and P. Pierson (eds) (1995), European Social Policy between Fragmentation and Integration, Washington: Brookings Institution.

Mancini, G.F. (2000), 'The making of a Constitution for Europe', in Democracy and Constitution in the European Union, Collected Essays, Oxford: Hart, pp. 1-16.

Martinsen, D.S. (2009), 'The Europeanization of healthcare governance: implementing the market imperatives of Europe', Public Administration, 86 (1), 169-84.

Neergaard, U. (2009), 'Services of general economic interest: the nature of the beast', in M. Krajewski, U. Neergaard and J. van de Gronden (eds), The Changing Legal Framework for Services of General Interest in Europe: Between Competition and Solidarity, The Hague: TMC Asser Press, pp. 17-50.

Piris, J.-C. (2006), 'Union européenne: comment rédiger une législation de qualité dans 20 langues et pour 25 États membres', Revue du Droit public de la Science politique en France et à l'étranger, 2, mars, 475-91.

Prosser, T. (2005), The Limits of Competition Law, Markets and Public Services, Oxford: Oxford University Press.

Rodière, P. (2008), Droit social de l'Union européenne, Paris: LGDJ.

Roman, D. (2010), 'La justiciabilité des droits sociaux ou les enjeux de l'édification d'un État de droit social', in D. Roman (ed.), Droits des pauvres, pauvres droits, recherches sur la justiciabilité des droits sociaux, Paris: EHESP CREDOF, pp. $1-40$.

Scharpf, F. (1999), Governing in Europe: Effective and Democratic?, Oxford: Oxford University Press.

Scharpf, F. (2010), 'The asymmetry of European integration, or why the EU cannot be a social market economy', Socio-Economic Review, 8 (2), 211-50.

Schmidt, V.A. (2006), Democracy in Europe: EU and National Polities, Oxford: Oxford University Press.

Streeck, W. (1998), 'De la construction du marché à la construction étatique? Réflexions sur l'économie politique de la politique sociale européenne', in S. Leibfried and P. Pierson (eds), Politiques sociales européennes, entre intégration et fragmentation, Paris: L'Harmattan, pp. 339-87.

Supiot, A. (2005), Homo juridicus: essai sur la fonction anthropologique du Droit, Paris: Seuil.

Supiot, A. (2009), L'esprit de Philadelphie, la justice sociale face au marché total, Paris: Seuil.

Vauchez, A. (2008), 'Integration-through-law: contribution to a socio-history of EU political commonsense', EUI Working Papers RCAS 2008/10, Florence: EUI.

Weiler, J.H.H. (1991), 'The transformation of Europe', Yale Law Journal, 100 (8), 2403-83. 


\section{APPENDIX}

\section{Table 1A.1 Relevant actors: Relationship to EU law and content of semi-structured interviews}

\begin{tabular}{llll}
\hline Actors & $\begin{array}{l}\text { Number of } \\
\text { interviews }\end{array}$ & $\begin{array}{l}\text { Relationship to EU law } \\
\text { and participation in EU } \\
\text { law making (soft and } \\
\text { hard) }\end{array}$ & $\begin{array}{l}\text { Topic (basis for } \\
\text { semi-structured } \\
\text { interviews) }\end{array}$ \\
&
\end{tabular}

\begin{tabular}{|c|c|c|c|}
\hline $\begin{array}{l}\text { 'National' actors in } \\
\text { national fora and } \\
\text { arenas (1) }\end{array}$ & 61 & & \\
\hline $\begin{array}{l}\text { Commercial actors/ } \\
\text { businesses }\end{array}$ & 6 & $\begin{array}{l}\text { Apply law/resist law/act } \\
\text { for developing their } \\
\text { share/litigate/negotiate } \\
\text { with public/lobby } \\
\text { authorities }\end{array}$ & $\begin{array}{l}\text { Influence of EU law, role } \\
\text { of competition and } \\
\text { government }\end{array}$ \\
\hline $\begin{array}{l}\text { NGOs, associations } \\
\text { and non-profit } \\
\text { (social services) }\end{array}$ & 20 & $\begin{array}{l}\text { Apply law/resist law/ } \\
\text { negotiate with public/act } \\
\text { for protecting their share/ } \\
\text { lobby national authorities }\end{array}$ & $\begin{array}{l}\text { Influence of EU law } \\
\text { (public procurement, } \\
\text { services directive, state } \\
\text { aid), role of private } \\
\text { competition and change, } \\
\text { quality of services; } \\
\text { OMCs* }\end{array}$ \\
\hline Unions & 5 & $\begin{array}{l}\text { Look for EU resources to } \\
\text { use in national fora and } \\
\text { arenas/lobby national } \\
\text { authorities }\end{array}$ & $\begin{array}{l}\text { Multi-level union action, } \\
\text { evolution of labour law } \\
\text { (national and EU); OMCs }\end{array}$ \\
\hline $\begin{array}{l}\text { Public authorities } \\
\text { and ministries }\end{array}$ & 20 & $\begin{array}{l}\text { Negotiate/transpose/ } \\
\text { adapt/link to EU law } \\
\text { decision/accommodate } \\
\text { lobbies }\end{array}$ & $\begin{array}{l}\text { Strategy with } \\
\text { Commission, } \\
\text { understanding and } \\
\text { applying law, negotiation } \\
\text { with actors, overall } \\
\text { provision and change; } \\
\text { OMCs }\end{array}$ \\
\hline $\begin{array}{l}\text { Legal experts: } \\
\text { (social services) + } \\
\text { labour law + EU } \\
\text { law }\end{array}$ & 9 & $\begin{array}{l}\text { Explain law; litigate on } \\
\text { behalf of actors; apply } \\
\text { law; interpret; create and } \\
\text { discuss; work with } \\
\text { authorities/lobby }\end{array}$ & $\begin{array}{l}\text { Understanding of EU } \\
\text { law; dynamic } \\
\text { development; articulation } \\
\text { of norms; role of legal } \\
\text { categories; hard and soft } \\
\text { law }\end{array}$ \\
\hline Politicians & 1 & $\begin{array}{l}\text { Use of EU law and EU } \\
\text { policy resources }\end{array}$ & $\begin{array}{l}\text { Role of the EU and local } \\
\text { politics }\end{array}$ \\
\hline $\begin{array}{l}\text { 'National' actors in } \\
\text { the EU fora and } \\
\text { arenas (2) }\end{array}$ & 27 & & \\
\hline
\end{tabular}




\begin{tabular}{|c|c|c|c|}
\hline Actors & $\begin{array}{l}\text { Number of } \\
\text { interviews }\end{array}$ & $\begin{array}{l}\text { Relationship to EU law } \\
\text { and participation in EU } \\
\text { law making (soft and } \\
\text { hard) }\end{array}$ & $\begin{array}{l}\text { Topic (basis for } \\
\text { semi-structured } \\
\text { interviews) }\end{array}$ \\
\hline Commercial actors & 2 & Lobby & $\begin{array}{l}\text { Current situation of } \\
\text { sector and EU law; } \\
\text { actions }\end{array}$ \\
\hline NGOs & 5 & Lobby & $\begin{array}{l}\text { Current situation of } \\
\text { sector and EU law; } \\
\text { actions }\end{array}$ \\
\hline Unions & 3 & Lobby & $\begin{array}{l}\text { Current situation of } \\
\text { social policy, labour law } \\
\text { and social services, union } \\
\text { action }\end{array}$ \\
\hline Legal scholars & 17 & $\begin{array}{l}\text { Interpret, create law; } \\
\text { work with formal } \\
\text { institutions; participate in } \\
\text { fora and in EU arenas; } \\
\text { lobby for EU law } \\
\text { formulation }\end{array}$ & $\begin{array}{l}\text { The EU legal order; } \\
\text { specific topics being } \\
\text { negotiated; } \\
\text { understanding EU legal } \\
\text { categories; hard and soft } \\
\text { law; innovation }\end{array}$ \\
\hline $\begin{array}{l}\text { Formal institutions } \\
\text { of the EU (3) } \\
\text { Council and EU } \\
\text { Parliament } \\
\text { (politicians) } \\
\text { Commission as } \\
\text { executive and } \\
\text { administration }\end{array}$ & $\begin{array}{r}12 \\
2 \\
10\end{array}$ & $\begin{array}{l}\text { Participate in EU politics } \\
\text { and as EU 'legislators' } \\
\text { Administer, negotiate, } \\
\text { accommodate lobbies, } \\
\text { politicise issues, } \\
\text { communicate, write texts }\end{array}$ & $\begin{array}{l}\text { Specific interviews } \\
\text { Law-making process; } \\
\text { present adaptation of } \\
\text { governance of social } \\
\text { policy (specific topics); } \\
\text { soft and hard law }\end{array}$ \\
\hline $\begin{array}{l}\text { Formal institutions } \\
\text { of the EU (4) CJEU } \\
\text { and Commission as } \\
\text { legal authorities }\end{array}$ & 4 & $\begin{array}{l}\text { Take decisions and legal } \\
\text { rulings, create case law }\end{array}$ & $\begin{array}{l}\text { The making of EU law; } \\
\text { EU and national law } \\
\text { articulation; EU legal } \\
\text { order; evolution of } \\
\text { primary law }\end{array}$ \\
\hline $\begin{array}{l}\text { Persons involved in } \\
\text { the translation of } \\
\text { texts (EU } \\
\text { institutions) (5) }\end{array}$ & 6 & $\begin{array}{l}\text { Explain, interpret, } \\
\text { translate, communicate }\end{array}$ & $\begin{array}{l}\text { Role of EU languages; } \\
\text { organisation of language } \\
\text { policy for legislation }\end{array}$ \\
\hline
\end{tabular}

Notes:

Multiple interviews with the same person over the four year period (2009-2012) are counted as different interviews. The total number of interviews does not include 6 case studies (social services and labour law) conducted by colleagues in the Czech Republic, the Netherlands and the UK nor the 26 semi-structured interviews conducted with experts by M. Hartlapp (see chapter 4 in this volume).

* OMC, Open Methods of Coordination. 